Bennett, M.A., V.A. Fritz, and N.W. Callan. 1992. Impacts of seed treatments on crop stand establishment. HortTechnology $2: 345-349$

Blackshaw, R.E. 1991. Soil temperature and moisture effects on downy brome vs. winter canola, wheat, and rye emergence. Crop Sci. 31:1034-1040.

Bosma, T.L., J.M. Dole, and N.O. Maness. 2003. Optimizing marigold (Tagetes erecta L.) petal and pigment yield. Crop Sci. (in press).

Danneberger, T.K., M.B. McDonald, Jr., C.A. Geron, and P. Kumari. 1992. Rate of germination and seedling growth of perennial ryegrass seed following osmoconditioning. HortScience 27:28-30.

Dole, J.M. and H.F. Wilkins. 1999. Floriculture principles and species. Prentice-Hall, Upper Saddle River, N.J.

Haigh, A.M, E.W. Barlow, and F.L. Milthorpe. 1986. Field emergence of tomato, carrot, and onion seeds primed in an aerated salt solution. J. Amer. Soc. Hort. Sci. $111: 660-665$.

Khan,A.A. 1992. Preplant physiological seed conditioning. Hort. Rev. 13:131-181.

Kondra, Z.P., D.C. Campbell, and J.R. King. 1983. Temperature effects on germination of rapeseed (Brassica napus L. and B. campestris L.). Can. J. Plant Sci. 63:377-384.

Livingston, N.J. and E. deJong. 1990. Matric and osmotic potential effects on seedling emergence at different temperatures. Agron. J. 36:459-466

Orchard, T.J. 1977. Estimating the parameters of plant seedling emergence. Seed Sci. Technol. 5:61-69.

Parera, C.A. and D.J. Cantliffe. 1994. Presowing seed priming. Hort. Rev. 16:109-141.

Pill, W.G., J.J. Frett, and I.H. Williams. 1997. Matric priming of kentucky bluegrass and tall fescue seeds benefits seedling emergence. HortScience 32:1061-1063

Rivas, M., F.J. Sundstrom, and R.L. Edwards. 1984. Germination and crop development of hot pepper after seed priming. HortScience 19:279-281.

Salac, S.S., J.M. Traeger, and P.N. Jensen. 1982. Seeding dates and field establishment of wildflowers. HortScience 17:805-806.

Wurr, D. and J. Fellows. 1983. The effect of the time of seedling emergence of crisp lettuce on the time of maturity and head weight at maturity. J. Hort. Sci. 58: 561-566.

Yamamoto, I., A.J. Turgeon, J.M. Duich. 1997. Field emergence of solid matrix seed primed turfgrasses. Crop Sci. 37: 220-225.

Hortlecthnotogy • July-September 2003 13(3)

\section{Efficacy of Paclobutrazol and Gibberellin on Growth and Flowering of Three Curcuma Species}

\author{
Mauricio J. Sarmiento and \\ Jeff S. Kuehny
}

Additional INDEX WORds. Curcuma alismatifolia, Curcuma gracillima, Curcuma thorelii, gibberellic acid, paclobutrazol, postproduction elongation, postproduction longevity

Summary. Rhizomes of Curcuma alismatifolia Roxb. 'Chiang Mai Pink', C. gracillima Roxb. 'Violet', and C. thorelii Roxb. were soaked in gibberellin $\left(\mathrm{GA}_{4+7}\right)$ at $0,200,400$, or 600 $\mathrm{mg} \cdot \mathrm{L}^{-1}(\mathrm{ppm})$ and planted into 15.2 $\mathrm{cm}$-diameter (6 inches) containers. The plants were grown in a greenhouse at $30{ }^{\circ} \mathrm{C}$ day $/ 23{ }^{\circ} \mathrm{C}$ night $(86.0 / 73.4$

$\left.{ }^{\circ} \mathrm{F}\right)$ temperatures. When shoot height was $10 \mathrm{~cm}$ (3.9 inches), the plants were drenched with $118 \mathrm{~mL}(3.9 \mathrm{fl} \mathrm{oz})$ of paclobutrazol at $0,2,3$, or $4 \mathrm{mg}$ a.i. per $15.2-\mathrm{cm}$-diameter container. Gibberellin $_{4+7}$ delayed shoot emergence and flowering but did not affect the flower number. Paclobutrazol rates were not effective in controlling height of C. alismatifolia 'Chiang Mai Pink' averaging $85 \mathrm{~cm}$ (33.5 inches), $C$. gracillima 'Violet' averaging $25 \mathrm{~cm}$ (9.8 inches), or C. thorelii averaging 17 $\mathrm{cm}$ (6.7 inches). Curcuma alismatifolia 'Chiang Mai Pink', C. gracillima 'Violet', and C. thorelii had postproduction longevities of 4.6, 2.6 and 3.8 weeks respectively, making these three species of curcuma excellent candidates for use as flowering pot plants.

$\mathrm{T}$ he genus Curcuma Roxb. includes about 65 species that are native to southeast Asia. Commonly known as hidden or surprise gingers, these plants possess an

137 Julian C. Miller Hall, Department of Horticulture, Louisiana State University Agricultural Center, Baton Rouge, LA 70803-2120.

Use of trade names dose not imply endorsement of the products named or criticism of similar ones not named. Louisiana State University manuscript number 01-28 0687. We would like to thank The Fred C. Gloeckne Foundation for supporting this research. We would also like to acknow de Scotts Co., Uniroyal Chenical, Novartis, Abbot Labs and Set Con Thailand fo providing material for this research. attractive inflorescence with colorful bracts that enclose the flowers (Steffey, 1986; Chapman, 1995). Curcuma exhibit diversity in color, form and size (Lekawatana and Pituck, 1998), and have few disease and insect problems (Kuack, 1996; Lekawatana and Pituck, 1998). Cultural practices and optimal environmental conditions for curcuma vary according to species. These plants are commonly propagated from geophytic units that include a rhizome and several storage roots, termed troots (Hagiladi et al., 1997). Curcuma rhizomes are planted in early spring, flower from early spring to late fall, and retain vegetative growth until late fall or early winter when senescence begins and plants go dormant in response to short days (Lekawatana and Pituck, 1998).

The international market for curcuma is increasing yearly (E. Welch, personal communication). In 1995, Thailand exported 15 million rhizomes valued at $\$ 3$ million, compared to $\$ 18,000$ exported in 1990 . Thailand exports curcuma rhizomes primarily to Japan and the Netherlands followed by the United States and New Zealand (Lekawatana and Pituck, 1998).

Curcuma alismatifolia, C. gracillima and $C$. thorelii have the most potential as flowering potted plants (Sarmiento, 2000). Curcuma alismatifolia has a terminal inflorescence with pink or white bracts, C. gracillima has a terminal inflorescence with red-white or red-violet bracts and $C$. thorelii has a white inflorescence (Chapman, 1995).

Marketable flowering potted plants are grown to a standard of 1.5 to 2 times the container height (Nelson, 1998). Some curcuma, C.alismatifolia' 'Chiang Mai Pink' for example, produce excessively tall inflorescences that result in unmarketable plants. These curcuma, however, possess other redeeming qualities as mentioned earlier and growth retardants offer a potential aid in the production of marketable potted plants.

Gibberellic acid $\left(\mathrm{GA}_{3}\right)$ increased the number and size of flowers on rhizomatous plants such as liatris (Liatris spicata L.) and calla lily (Zantedeschia elliottiana W. Wats. and Z. rehmannii Engl.) (Corr and Widmer, 1991; Wanjao and Waithaka, 1983). Gibberellic acid reduced flower and shoot number and in some cases inhibited flowering of edible ginger (Zingiber officinale Roscoe) 'Chinese' (Furutani and Nagao, 1986). In potatoes (Solanum 
tuberosumL.), exogenous $\mathrm{GA}_{3}$ reduced tuberization on whole plants, cuttings or in vitro plants (Ewing, 1997). GA applied to seed pieces by dip or spray, however, promoted sprout growth breaking dormancy and stimulated sprout elongation (Mikitzel and Fuller, 1995). In fruit crops, $\mathrm{GA}_{3}$ is used as a fruit setting agent in some species and a fruit thinner in other species.

Postproduction longevity is important to the development and introduction of new crops in the floriculture industry (Nell and Barrett, 1989). Flower quality must be maintained in spite of low light conditions provided by the retailer and final consumer (Armitage, 1986, Plummer et al., 1990). Evaluation of the interior performance offlowering pot plants contributes to a successful market strategy and assures consumer acceptance (Nell and Barret, 1989).

The objectives of this research were to determine 1) the effects of $\mathrm{GA}_{4+7}$ on rhizome emergence of $C$. alismatifolia 'Chiang Mai Pink', C. thorelii, and C. gracillima 'Violet' and 2) the effects of $\mathrm{GA}_{4+7}$ and paclobutrazol on days to bloom, inflorescence height and number, postproduction longevity and elongation.

\section{Materials and methods}

Rhizomes [ $1 \mathrm{~cm}(0.4$ inch $)]$ of Curcuma alismatifolia 'Chiang Mai Pink', C. gracillima 'Violet', and C. thorelii were soaked for $10 \mathrm{~min}$ in a solution containing $\mathrm{GA}_{4+7}$ (Provide; Abbot Labs, North Chicago, Ill.) at $0,200,400$, or $600 \mathrm{mg} \cdot \mathrm{L}^{-1} ; 100,000$ $\mathrm{mg} \cdot \mathrm{L}^{-1}$ Physan 20 (a.i. dimethyl benzyl ammonium chloride and dimethyl ethyl ammonium chloride; Maril Products, Tustin, Calif.) and distilled water. Rhizomes were dried and planted one per 15.2-cm-diameter container filled with a medium consisting of $50 \%$ peatmoss, $30 \%$ pine bark, and $20 \%$ perlite $(\mathrm{v} / \mathrm{v})$, amended with $5.1 \mathrm{~kg} \cdot \mathrm{m}^{-3}\left(0.32 \mathrm{lb} / \mathrm{yard}^{3}\right)$ dolomite limestone and superphosphate $2.7 \mathrm{~kg} \cdot \mathrm{m}^{-3}\left(0.17 \mathrm{lb} /\right.$ yard $\left.^{3}\right) 0 \mathrm{~N}-18 \mathrm{P}-0 \mathrm{~K}$ on 17 Apr. 1999.

Plants were placed in a greenhouse on $20.3 \times 20.3-\mathrm{cm}(8$-inch $)$ centers and drenched with a tank mix of metalaxyl (Subdue 2E; Novartis, Greensboro, N.C.) and PCNB quintozene (Terraclor 75\% WP; Uniroyal Chemical Co., Middlebury, Conn.). Plants were fertilized with $150 \mathrm{mg} \cdot \mathrm{L}^{-1}$ nitrogen $(\mathrm{N})$ using $24 \mathrm{~N}-3.5 \mathrm{P}-13.3 \mathrm{~K}$ (Peters $24-8-16$ Tropical Foliage; Scotts Co., Marysville, Ohio). When shoots were $10.2 \mathrm{~cm}(4$ inches) tall, substrates were drenched with $118 \mathrm{~mL}$ paclobutrazol (Bonzi; Uniroyal Chemical Co.) at $0,2,3$, or 4 $\mathrm{mg}$ a.i. per $15.2-\mathrm{cm}$-diameter container. All plants received ambient light levels in the greenhouse.

When the last bract and one flower opened (marketable stage), days to emergence and days to bloom were determined from date of planting. Number of flowers and height of the inflores- cence stalk were recorded for all plants. Once measured, plants were moved to a postproduction room maintained at $20^{\circ} \mathrm{C}\left(68.0^{\circ} \mathrm{F}\right)$ with $12 \mathrm{~h}$ of light at 14 umol $\cdot \mathrm{m}^{-2} \cdot \mathrm{s}^{-1}$. Flower height and quality were measured on a weekly basis until senescence of the final flower. Flower height was determined by measuring the length of the petiole from the pot rim to the tip of the inflorescence. Postproduction elongation was determined by the difference in height of the inflorescence spike at the marketable stage and the last week that the plants maintained an acceptable quality. Visual quality was measured on a scale from 1 to 5 . The scale was defined as follows: 1 ) a plant with perfect quality received 5,2 ) a rating between 4 and 5 was assigned to plants with no necrosis and bright and intense pink bracts, 3 ) ratings between 3 and 4 were assigned to plants without necrosis and with pink bracts in which the color begins to fade, 4 ) plants that received a rating between 2.5 and 3 had no necrosis but presented significant color loss of the pink bracts, 5) plants with necrotic bracts and with poor coloration were not considered acceptable and received a rating below $2.5,6$ ) flowers that had completed senescence received a rating of 1 . Data for each curcuma species were subjected to analysis of variance separately using a completely randomized design with ten replicates (plants) per treatment. Tukey's studentized range test was used for mean separation.

Table 1. Effect of gibberellin ${ }_{4+7}\left(\mathrm{GA}_{4+7}\right)$ and paclobutrazol on days to emergence, days to bloom, flower height (measured from pot rim to top of plant), postproduction longevity, and postproduction elongation of Curcuma alismatifolia 'Chiang Mai Pink'.

\begin{tabular}{|c|c|c|c|c|c|}
\hline Chemical & $\begin{array}{l}\text { Days to } \\
\text { emergence }\end{array}$ & $\begin{array}{l}\text { Days to } \\
\text { bloom }\end{array}$ & $\begin{array}{c}\text { Flower } \\
\text { ht } \\
(\mathrm{cm})^{z}\end{array}$ & $\begin{array}{c}\text { Postproduction } \\
\text { longevity } \\
\text { (weeks) }\end{array}$ & $\begin{array}{l}\text { Postproduction } \\
\text { elongation } \\
(\mathrm{cm})\end{array}$ \\
\hline \multicolumn{6}{|l|}{$\mathrm{GA}_{4+7}\left[\left(\mathrm{mg} \cdot \mathrm{L}^{-1}(\mathrm{ppm})\right]\right.$} \\
\hline 0 & $44 \mathrm{a}^{y}$ & $113 \mathrm{a}$ & $92 \mathrm{~b}$ & $4.8 \mathrm{a}$ & $1.8 \mathrm{a}$ \\
\hline 200 & $53 \mathrm{~b}$ & $115 \mathrm{ab}$ & $89 \mathrm{ab}$ & $4.2 \mathrm{a}$ & $2.0 \mathrm{a}$ \\
\hline 400 & $57 \mathrm{~b}$ & $128 \mathrm{~b}$ & $88 \mathrm{ab}$ & $4.4 \mathrm{a}$ & $2.2 \mathrm{a}$ \\
\hline 600 & $55 \mathrm{~b}$ & $126 \mathrm{ab}$ & $86 \mathrm{a}$ & $5.0 \mathrm{a}$ & $3.0 \mathrm{a}$ \\
\hline \multicolumn{6}{|l|}{ Paclobutrazol (mg a.i. ) } \\
\hline 0 & & $118 \mathrm{a}$ & $88 \mathrm{ab}$ & $4.5 \mathrm{a}$ & $1.7 \mathrm{a}$ \\
\hline 2 & & $117 \mathrm{a}$ & $91 \mathrm{~b}$ & $4.8 \mathrm{a}$ & $2.3 \mathrm{a}$ \\
\hline 3 & & $125 \mathrm{a}$ & $85 \mathrm{a}$ & $4.6 \mathrm{a}$ & $2.8 \mathrm{a}$ \\
\hline 4 & & $122 \mathrm{a}$ & $90 \mathrm{ab}$ & $4.5 \mathrm{a}$ & $2.3 \mathrm{a}$ \\
\hline Pooled means & 52 & 120 & 88 & 4.6 & 2.2 \\
\hline $\mathrm{GA}_{4+7}$ & $* * *$ & * & * & NS & NS \\
\hline Paclobutrazol & $--^{x}$ & NS & * & NS & NS \\
\hline $\mathrm{GA}_{4+7} \times$ paclobutrazol & --- & NS & NS & NS & * \\
\hline
\end{tabular}




\section{Results}

Gibberellin $_{4+7}$ at 200, 400 and $600 \mathrm{mg} \cdot \mathrm{L}^{-1}$ significantly delayed shoot emergence of C. alismatifolia 'Chiang Mai Pink' (Table 1). Gibberellin ${ }_{4+7}$ at $400 \mathrm{mg} \cdot \mathrm{L}^{-1}$, delayed flowering by approximately 1 week and did not increase the number of inflorescences. All plants had one inflorescence per container. Paclobutrazol did not affect number of days to bloom. Application of $\mathrm{GA}_{4+7}$ at 600 $\mathrm{mg} \cdot \mathrm{L}^{-1}$ resulted in a flower height $6 \mathrm{~cm}$ (2.4 inches) shorter than the control, while paclobutrazol applied at $3 \mathrm{mg}$ a.i. per pot produced flowers $6 \mathrm{~cm}$ shorter than the $2 \mathrm{mg}$ a.i. per pot. None of the rates of paclobutrazol however, reduced flower height compared to the control.

Paclobutrazol and $\mathrm{GA}_{4+7}$ did not affect postproduction longevity or elongation of C. alismatifolia 'Chiang Mai Pink'. The combination of $0 \mathrm{mg} \cdot \mathrm{L}^{-1} \mathrm{GA}_{4+7}$ and $4 \mathrm{mg}$ a.i. paclobutrazol, however, significantly reduced postproduction elongation $[0.51 \mathrm{~cm}(0.2$ inch $)]$ more than the combination of $600 \mathrm{mg} \cdot \mathrm{L}^{-1} \mathrm{GA}_{4+7}$ and $4 \mathrm{mg}$ a.i. paclobutrazol $[5.1 \mathrm{~cm}$ (2 inches)] (data not presented). Acceptable postproduction longevity was determined to be 4.6 weeks (Table 4 ). This was indicated by a postproduction quality rating $\geq 4$ for 2.4 weeks and $\geq$ 2.5 for 4.6 weeks. Senescence (rating of 1 ) occurred after 6.3 weeks. Neither $\mathrm{GA}_{4+7}$ nor paclobutrazol affected quality ratings throughout the postproduction study (data not shown).

Gibberellin $_{4+7}$ concentrations of $600 \mathrm{mg} \cdot \mathrm{L}^{-1}$ delayed shoot emergence of C.gracillima 'Violet' and C. thorelii

Table 2. Effect of gibberellin ${ }_{4+7}\left(\mathrm{GA}_{4+7}\right)$ and paclobutrazol on days to emergence, days to bloom, flower height (measured from pot rim to top of plant), postproduction longevity, and postproduction elongation of Curcuma gracillima 'Violet'.

\begin{tabular}{|c|c|c|c|c|c|}
\hline Chemical & $\begin{array}{c}\text { Days to } \\
\text { emergence }\end{array}$ & $\begin{array}{c}\text { Days to } \\
\text { bloom }\end{array}$ & $\begin{array}{c}\text { Flower } \\
\mathrm{ht} \\
\left(\mathrm{cm}^{\mathrm{z}}\right)\end{array}$ & $\begin{array}{c}\text { Postproduction } \\
\text { longevity } \\
\text { (weeks) }\end{array}$ & $\begin{array}{l}\text { Postproduction } \\
\text { elongation } \\
(\mathrm{cm})\end{array}$ \\
\hline \multicolumn{6}{|l|}{$\mathrm{GA}_{4,7}\left[\left(\mathrm{mg} \cdot \mathrm{L}^{-1}(\mathrm{ppm})\right]\right.$} \\
\hline 0 & $40.5 a^{y}$ & $108 \mathrm{a}$ & $23.8 \mathrm{a}$ & $2.3 \mathrm{a}$ & $1.2 \mathrm{a}$ \\
\hline 200 & $44.6 \mathrm{ab}$ & $114 \mathrm{a}$ & $26.1 \mathrm{a}$ & $2.0 \mathrm{a}$ & $0.9 \mathrm{a}$ \\
\hline 400 & $44.6 \mathrm{ab}$ & $109 \mathrm{a}$ & $25.2 \mathrm{a}$ & $2.3 \mathrm{a}$ & $1.5 \mathrm{a}$ \\
\hline 600 & $47.9 \mathrm{~b}$ & $121 \mathrm{a}$ & $26.8 \mathrm{a}$ & $3.2 \mathrm{a}$ & $1.3 \mathrm{a}$ \\
\hline \multicolumn{6}{|l|}{ Paclobutrazol (mg a.i.) } \\
\hline 0 & & $114 \mathrm{a}$ & $28.6 \mathrm{a}$ & $2.2 \mathrm{a}$ & $1.0 \mathrm{a}$ \\
\hline 2 & & $111 \mathrm{a}$ & $26.8 \mathrm{a}$ & $2.1 \mathrm{a}$ & $0.9 \mathrm{a}$ \\
\hline 3 & & $114 \mathrm{a}$ & $24.0 \mathrm{a}$ & $2.6 \mathrm{a}$ & $1.5 \mathrm{a}$ \\
\hline 4 & & $112 \mathrm{a}$ & $22.5 \mathrm{a}$ & $2.9 \mathrm{a}$ & $1.3 \mathrm{a}$ \\
\hline Pooled means & 44 & 113 & 25.3 & 2.6 & 1.3 \\
\hline $\mathrm{GA}_{4+7}$ & * & NS & NS & NS & NS \\
\hline Paclobutrazol & $--^{x}$ & NS & NS & NS & NS \\
\hline $\mathrm{GA}_{4+7} \times$ paclobutrazol & --- & NS & NS & NS & NS \\
\hline
\end{tabular}

${ }^{2} 1 \mathrm{~cm}=2.54$ inches.
${ }^{y}$ Means within a column followed by different letters are significantly different from each other by Tukey's studentized range test, $P=0.05$. Means are an average of 10 yeans within a column followed by different letters are significantly different from each other by Tukey's studentized range test, $P=0.05$. Means are an average of 10
replications. ×Paclobutrazol was applied after emergence.

ws,,$* * *$ Nonsignificant or significant at $P \leq 0.05$ or 0.001 , respectively.

Table 3. Effect of gibberellin ${ }_{4+7}\left(\mathrm{GA}_{4+7}\right)$ and paclobutrazol on days to emergence, days to bloom, flower height (measured from pot rim to top of plant), postproduction longevity, and postproduction elongation of Curcuma thorelii.

\begin{tabular}{|c|c|c|c|c|c|}
\hline Chemical & $\begin{array}{c}\text { Days to } \\
\text { emergence }\end{array}$ & $\begin{array}{c}\text { Days to } \\
\text { bloom }\end{array}$ & $\begin{array}{c}\text { Flower } \\
\text { ht } \\
\left(\mathrm{cm}^{z}\right)\end{array}$ & $\begin{array}{c}\text { Postproduction } \\
\text { longevity } \\
\text { (weeks) }\end{array}$ & $\begin{array}{l}\text { Postproduction } \\
\text { elongation } \\
(\mathrm{cm})\end{array}$ \\
\hline \multicolumn{6}{|l|}{$\mathrm{GA}_{4+7}\left[\left(\mathrm{mg} \cdot \mathrm{L}^{-1}(\mathrm{ppm})\right]\right.$} \\
\hline 0 & $40.2 \mathrm{a}^{\mathrm{y}}$ & $113 \mathrm{a}$ & $16.0 \mathrm{a}$ & $4.3 \mathrm{a}$ & $0.9 \mathrm{a}$ \\
\hline 200 & $43.7 \mathrm{ab}$ & $115 \mathrm{a}$ & $17.7 \mathrm{a}$ & $4.1 \mathrm{a}$ & $1.2 \mathrm{a}$ \\
\hline 400 & $45.0 \mathrm{ab}$ & $113 \mathrm{a}$ & $17.5 \mathrm{a}$ & $3.6 \mathrm{a}$ & $0.5 \mathrm{a}$ \\
\hline 600 & $51.2 \mathrm{~b}$ & $131 \mathrm{a}$ & $17.1 \mathrm{a}$ & $3.8 \mathrm{a}$ & $0.5 \mathrm{a}$ \\
\hline \multicolumn{6}{|l|}{ Paclobutrazol (mg a.i.) } \\
\hline 0 & & $121 \mathrm{a}$ & $17.8 \mathrm{a}$ & $4.5 \mathrm{a}$ & $0.4 \mathrm{a}$ \\
\hline 2 & & $125 \mathrm{a}$ & $17.4 \mathrm{a}$ & $3.2 \mathrm{a}$ & $0.7 \mathrm{a}$ \\
\hline 3 & & $109 \mathrm{a}$ & $17.3 \mathrm{a}$ & $3.9 \mathrm{a}$ & $1.3 \mathrm{a}$ \\
\hline 4 & & $116 \mathrm{a}$ & $15.8 \mathrm{a}$ & $4.3 \mathrm{a}$ & $0.9 \mathrm{a}$ \\
\hline Pooled means & 44 & 117 & 17.3 & 3.8 & 0.8 \\
\hline $\mathrm{GA}_{4+7}$ & * & NS & NS & NS & NS \\
\hline paclobutrazol & $--{ }^{x}$ & NS & NS & NS & NS \\
\hline $\mathrm{GA}_{4+7} \times$ paclobutrazol & --- & NS & NS & NS & NS \\
\hline
\end{tabular}

${ }^{\mathrm{z}} \mathrm{cm}=2.54$ inches. yeans within a column followed by different letters are significantly different from each other by Tukey's studentized range test, $P=0.05$. Means are an average of 10
replications. replications.

xPaclobutrazol was applied after emergence.

ss,,,$* * *$ Nonsignificant or significant at $P \leq 0.05$ or 0.001 , respectively. 
Research Reports

Table 4. Postproduction longevity (weeks) at 4, 3, 2.5, 2, and 1 quality ratings and standard errors following production of Curcuma alismatifolia 'Chiang Mai Pink', C. gracillima 'Violet' and C. thorelii.

\begin{tabular}{lccc}
\hline $\begin{array}{l}\text { Quality } \\
\text { rating }\end{array}$ & $\begin{array}{c}\text { C. alismatifolia } \\
\text { 'Chiang Mai Pink' }\end{array}$ & $\begin{array}{c}\text { C. gracillima } \\
\text { 'Violet' }\end{array}$ & C. thorelii \\
\hline$\geq 4$ & $2.4 \pm 0.1$ & $2.2 \pm 0.3$ & $3.4 \pm 0.2$ \\
$\geq 3$ & $4.1 \pm 0.1$ & $2.6 \pm 0.3$ & $3.6 \pm 0.3$ \\
$\geq 2.5$ & $4.6 \pm 0.2$ & $2.7 \pm 0.2$ & $3.9 \pm 0.3$ \\
$\geq 2$ & $5.3 \pm 0.2$ & $3.0 \pm 0.3$ & $4.5 \pm 0.3$ \\
$\geq 1$ & $6.3 \pm 0.2$ & $3.9 \pm 0.3$ & $5.5 \pm 0.3$ \\
\hline
\end{tabular}

${ }^{2}$ Visual quality was measured on a scale from 1 to 5 . The scale was defined as follows: 1 ) a plant with perfect quality received 5,2 ) a rating between 4 and 5 was assigned to plants with no necrosis and bright and intense pink bracts, 3 ) ratings between 3 and 4 were assigned to plants without necrosis and with pink bracts in which the color begins to fade, 4 ) plants that received a rating between 2.5 and 3 had no necrosis but presented significant color loss of the pink bracts, 5) plants with necrotic bracts and with poor coloration were not considered acceptable and received a rating below $2.5,6$ ) flowers that had completed senescence received a rating of 1 .

(Tables 2 and 3). Neither paclobutrazol nor $\mathrm{GA}_{4+7}$ affected flower height or days to bloom of C. gracillima 'Violet' nor C. thorelii. Similar results were indicated for number of inflorescences. Plants developed no more than one flowering stem.

Postproduction longevity or elongation of C. gracillima 'Violet' or $C$. thorelii was not affected by $\mathrm{GA}_{4+7}$ or paclobutrazol (data not presented). The postproduction life of C.gracillima 'Violet' was 2.6 weeks and elongation was $1.3 \mathrm{~cm}(0.51$ inches) (Table 2). During the postproduction period, plants maintained a quality rating $\geq 4$ for 2.2 weeks, $\geq 2.5$ for 2.7 weeks and reached senescence (rating 1) after 3.9 weeks (Table 4). Postproduction longevity of C. thorelii was 3.8 weeks and elongation was $0.8 \mathrm{~cm}(0.32$ inches ) (Table 3 ), while plants maintained a quality rating $\geq 4$ for 3.4 weeks, $\geq 2.5$ for 3.9 weeks and reached senescence after $\mathbf{5 . 5}$ weeks (Table 4).

\section{Discussion}

Gibberellin $_{4+7}$ did not increase inflorescence number of the three Curcuma species grown in this study. Gibberellin $_{4+7}$ at $600 \mathrm{mg} \cdot \mathrm{L}^{-1}$, however, delayed shoot emergence as much as $11 \mathrm{~d}$ but did not inhibit it. Foliar application of GA applied at concentrations of 1.44 and $2.88 \mathrm{~mm}$ suppressed shoot emergence of field grown edible ginger (Furutani and Nagao, 1986). Okwuowulu and Nnodu (1988) applied $\mathrm{GA}_{3}$ at $150 \mathrm{mg} \cdot \mathrm{L}^{-1}$ as a 24 -h dip to determine the effect of a pre-storage chemical treatment on the storability of edible ginger. This treatment rate was not observed to be effective in controlling sprouting and higher rates were suggested. Gibberellic acid has been recommended for extending dormancy, thereby inhibiting sprouting in storage of yams (Dioscorea cayenensis rotundata Lam. and D. alata L.), an edible tuber (Girardin et al., 1998). These studies and the $\mathrm{GA}_{4+7}$ research conducted in this study suggests that gibberellin might be used to prolong storage of ornamental ginger rhizomes prior to planting. Gibberellin should not be used to promote or increase flowering as indicated for calla lily (Corr and Widmer, 1991).

Gibberellic acid stimulated stem elongation (Nelson, 1998). Gibberel$\operatorname{lin}_{4+7}$ at $600 \mathrm{mg} \cdot \mathrm{L}^{-1}$ significantly reduced flower height of C.alismatifolia 'Chiang Mai Pink' by $6.5 \%$. Similar results were found in yams (D. cayenensisrotundata), where $\mathrm{GA}_{3}$ at $150 \mathrm{mg} \cdot \mathrm{L}^{-1}$ as a tuber soak reduced stem length by $63 \%$ (Girardin et al., 1998; Igwilo, 1988).

The most effective rate of paclobutrazol on C. alismatifolia 'Chiang Mai Pink' was $3 \mathrm{mg}$ a.i., which produced plants $85.3 \mathrm{~cm}$ (33.58 inches) tall. The standard height of a flowering pot plant grown in a $15.2-\mathrm{cm}$-diameter container should be 22 to $30 \mathrm{~cm}(8.7$ to 11.8 inches). Thus, higher rates of paclobutrazol or the use of other growth retardants must be evaluated in order to determine efficacy on plant height. Curcuma gracillima 'Violet' and $C$. thorelii, propagated by $1-\mathrm{cm}$ rhizomes, are naturally low growing plants. Average height for all treatments was 25.3 $\mathrm{cm}$ (9.96 inches) for $C$. gracillima 'Violet' and $17.3 \mathrm{~cm}$ (6.69 inches) for C. thorelii. Thus, the use of a PGR does not appear to be necessary.

Curcumaalismatifolia 'Chiang Mai Pink' had an excellent postproduction life of 4.6 weeks and little postproduction elongation $[2.3 \mathrm{~cm}(0.91$ inch $)]$. Postproduction elongation was not significant for C. thorelii or C. gracillima 'Violet' while postproduction longevity was also very good at 3.8 weeks and shorter at 2.6 weeks, respectively.
These attributes along with those previously discussed, indicate that these three curcuma species are excellent candidates for flowering pot plants and should be considered as an alternative crop.

\section{Literature cited}

Armitage, A.M. 1986. Evaluation for new floricultural crops: A systems approach. HortScience 21:9-11.

Chapman, T.S. 1995. Ornamental gingers, a guide to selection and cultivation. Chapman Press, Baton Rouge, La.

Corr,B.E. and R.E. Widmer. 1991. Paclobutrazol, gibberellic acid and rhizome size affect growth and flowering of Zantedeschia. HortScience 26: 133-135.

Ewing, E.E. 1997. Potato, p. 314-316. In: H.C. Wien (ed.). The physiology of vegetable crops. CAB Intl., Wallingford, U.K.

Furutani, S.C. and M.A. Nagao. 1986. Influence of daminozide, gibberellic acid and ethephon on flowering, shoot growth and yield of ginger. HortScience 21:428-429.

Girardin, O., C. Nindjin, Z. Farah, F. Escher, P. Stamp, and D. Otokore. 1998. Use of gibberellic acid to prolong dormancy and reduce losses during traditional storage of yams. J. Sci. Food Agr. 77:172-178.

Hagiladi, A., N. Umiel, Z Gilad, and X.H. Yang. 1997. Curcuma alismatifolia. I. Plant morphology and the effect of tuberous root number on flowering date and yield of inflorescences. Acta Hort. 430:755-761.

Igwilo, N. 1988. Inhibition of sprouting by gibberellic acid in the preservation of seed and ware yam. Beitr. Trop. Landwirtsch. Veterinarmed 26: $145-154$.

Kuack, D. 1996. A how-to production guide: Curcuma. Greenhouse Mgt. Prod. 16:8.

Lekawatana, S. and O. Pituck.1998. New floricultural crops in Thailand. Acta Hort. 454:59-63.

Mikitzel, L.J. and N. Fuller. 1995. Dry gibberellic acid combined with talc or fir bark enhances early stem and tuber growth of shepody potato. Amer. Potato J. 72:545-551

Nell, T.A. and J.E. Barrett. 1989. Postproduction longevity of new flowering potted plants. Acta Hort. 252:87-89.

Nelson, P.V. 1998. Chemical growth regulation. Greenhouse operation and management. Prentice Hall, Upper Saddle River, N.J.

Okwuowulu, P.A. and E.C. Nnodu. 1988. Somme effects of pre-storage chemical treatments and age at harvesting on the storability of fresh ginger rhizomes (Zingiber officinale Roscoe). Trop. Sci. 28:123-125.

Plummer, J.A., T.E. Welsh, and A.M. Armitage. 1990. Stages of flowering development and postproduction longevity of potted Zantedeschia aethiopica 'Childsiana'. HortScience 25:675-676.

Sarmiento, M.J. 2000. Effect of production prac tices on growth and development of Zingiberaceae. MS thesis. La. State Univ., Baton Rouge.

Steffey, J. 1986. The ginger family. Amer. Hort 65:6-9.

Wanjao, L.W. and K. Waithaka. 1983. The effect of GA3-application on growth and flowering of Liatris. Sci. Hort. 19:343-348. 